\title{
Wykorzystanie techniki swobodnych tekstów C. Freineta dla wspomagania rozwoju mowy i myślenia w języku obcym u studentów neofilologii *
}

\author{
Using C. Freinent's free text technique to support foreign language \\ speech and thinking in Neophilology students
}

\author{
Zdzisław ALEKSANDER ${ }^{1}$ \\ Ateneum-Szkoła Wyższa w Gdańsku
}

\begin{abstract}
In everyday practice, the university has a task of shaping the intellect and developing the mental culture of students. The creative and active character of a person's personality is manifested and shaped in the process of exteriorization and expression. Based on the concept of language and thinking, attention should be paid to the particular importance of verbal expression. The basis here is the hypothesis that thought is realized in a word. As we develop a language, we also increase opportunities for externalization and improvement of thought. The article emphasizes values of verbal expression and its role in the personal experience and assimilation of the world, in shaping creative attitudes. The author recommends linking creative work of neophilology students to the mastery of a foreign language with the formation of their intellect and humanistic attitudes. Such conditions enabling, on the one hand, the improvement and enrichment of language skills and, on the other hand, free expression of one's thoughts are
\end{abstract}

\footnotetext{
* Przy tworzeniu tego artykułu korzystałem z materiałów udostępnionych mi przez dr Wandę Frankiewicz. Jest on nawiązaniem do napisanego wcześniej wspólnego tekstu (Aleksander, Frankiewicz, 2014).

1 https://orcid.org/0000-0002-4281-7890

Ateneum-Szkoła Wyższa w Gdańsku, Wydział Studiów Edukacyjnych

z.aleksander@ateneum.edu.pl
} 
created by learning based on the technique of free text developed by French educator C. Freinet. The article shows how the technique of free text can not only be an auxiliary element, but can become a starting point and crucial issue in the work on the practical mastery of a foreign language and intellectual development of students, as well as how to anchor the improvement of language skills in intelligence, dynamics and expression of future language teachers.

Keywords: Neophilology student, free text technique, speech and thinking development

\section{Streszczenie}

W codziennej praktyce przed uczelnią wyższą stoi zadanie kształtowania intelektu i wyrabiania kultury umysłowej studentów. Twórczy i aktywny charakter osobowości człowieka objawia się i kształtuje w procesie eksterioryzacji, ekspresji. Opierając się na koncepcji języka i myślenia należałoby zwrócić uwagę na szczególne znaczenie ekspresji słownej. Podstawą jest tu teza, że myśl realizuje się w słowie. Gdy kształcimy język, zwiększamy także możliwości uzewnętrznienia i doskonalenia myśli. W artykule akcentowane są wartości ekspresji słownej, jej rola w osobistym przeżywaniu i przyswajaniu świata, w kształtowaniu postaw twórczych. Autor rekomenduje powiązanie twórczej pracy studentów neofilologii nad opanowywaniem języka obcego z kształtowaniem ich intelektu i postaw humanistycznych. Takie warunki, umożliwiające z jednej strony doskonalenie i wzbogacanie umiejętności językowych, z drugiej - swobodne wyrażanie swoich myśli, stwarza uczenie się zorganizowane techniką swobodnych tekstów, opracowaną przez francuskiego pedagoga C. Freineta. W artykule ukazano, jak technika swobodnych tekstów może być nie tylko elementem pomocniczym, lecz może stać się punktem wyjścia i punktem centralnym w pracy nad praktycznym opanowaniem języka obcego i intelektualnym rozwojem studentów, a także jak można opierać pracę nad doskonaleniem umiejętności językowych na inteligencji, dynamice, ekspresji przyszłych nauczycieli języków. Słowa kluczowe: student neofilologii, technika swobodnych teksów, rozwój mowy i myślenia

\section{Wprowadzenie - aspekty teoretyczne problemu}

W codziennej praktyce przed uczelnią wyższą stoi zadanie kształtowania intelektu i wyrabiania kultury umysłowej studentów. Intelekt jest więc głównym narzędziem, którym musi się posługiwać studiujący zarówno na uczelni, jak i później w pracy pedagogicznej. Dlatego za trafne należy uznać określenie zarówno samego studiowania jak i pracy nauczycielskiej jako „swoistej przygody człowieka myślącego” (Rutkowiak 2016).

Teoretyczną podstawą takiego ujęcia jest koncepcja osobowości, w której człowiek traktowany jest jako układ samodzielny, odbierający informacje z otoczenia i przetwarzający je. Można powiedzieć, że istotny dla funkcjonowania jednostki jest jej wielowymiarowy układ informacyjny. Informacja, przyswajana w czasie studiów nie może być interpretowana tylko jako wiedza o rzeczywistości stanowiąca swoisty nabytek, zasób sfery intelektualnej przyszłego filologa. Staje się ona podstawą całego systemu 
regulacyjnego, bogacącego widzenie świata i decydującego o funkcjonowaniu studenta najpierw $\mathrm{w}$ uczelni, a następnie $\mathrm{w}$ warunkach pracy zawodowej. Czynnikiem mobilizującym do aktywności intelektualnej i twórczej postawy jest w zawodzie nauczycielskim dynamika sytuacji, które trzeba rozwiązywać.

Twórczy i aktywny charakter osobowości człowieka objawia się i kształtuje w procesie eksterioryzacji, ekspresji. Rzeczywiste przyswajanie sobie wiedzy i umiejętności zachodzi wówczas, kiedy próbujemy coś wytwarzać. Wtedy nasza wiedza staje się operatywna. Tak więc, kształtowanie „postawy otwartego umysłu” powinno uwzględniać przeżyciową, ekspresyjną postać działalności studenta neofilologii. Ekspresja jest zawsze związana z twórczą działalnością jednostki. Nie jest ona tylko prostym odtworzeniem, odbiciem uwewnętrznionego świata, ale także jakąś interpretacją, przetworzeniem.

Opierając się na powszechnie przyjętej koncepcji języka i myślenia należałoby zwrócić uwagę na szczególne znaczenie ekspresji słownej. Podstawą jest tu znana teza L. S. Wygotskiego (1989) mówiąca, że myśl realizuje się $\mathrm{w}$ słowie. Nie istnieje ona $\mathrm{W}$ gotowej i skończonej postaci, lecz jest kształtowana zawsze w jakimś języku i jej struktura zależy od struktury tego języka. Tak rozumiany związek języka i myślenia zezwala na przyjęcie oczywistego, jak się wydaje, założenia, że zawsze wtedy, gdy kształcimy język, zwiększamy także możliwości uzewnętrznienia i doskonalenia myśli.

Będą więc w dalszej części tego artykułu akcentowane wartości ekspresji słownej, jej rola w osobistym przeżywaniu i przyswajaniu świata, w kształtowaniu postaw twórczych. Chcę także zarekomendować powiązanie twórczej pracy studentów neofilologii nad opanowywaniem języka obcego z kształtowaniem ich intelektu i postaw humanistycznych.

Współczesna teoria komunikacji traktuje język nie tylko jako środek wyrażania wewnętrznych przeżyć, ale głównie jako narządzie komunikacji społecznej i narzędzie poznawania świata. W naturalnym zachowaniu werbalnym studenta tkwi ogromne bogactwo jego uczuć, myśli, spostrzeżeń i różnorodnych doświadczeń. Należałoby je włączyć w proces kształcenia językowego tak, aby przygotowując do posługiwania się językiem obcym, pogłębiać wiedzę o przyszytych neofilologów o świecie i wzbogacać ich osobowość. Chodzi tu o takie organizowanie nauczania, by umożliwić swobodne wyrażanie myśli, by studenci mieli o czym mówić i pisać w języku obcym, aby chcieli dzielić się $\mathrm{z}$ innymi swoimi spostrzeżeniami. Chodzi również o to, aby nie oddzielać w sposób sztuczny nauki o języku od samego procesu kształcenia języka (Freinet 1963). 
Takie warunki, umożliwiające $\mathrm{z}$ jednej strony doskonalenie i wzbogacanie umiejętności językowych, z drugiej - swobodne wyrażanie swoich myśli stwarza nauczanie zorganizowane techniką swobodnych tekstów, opracowaną przez francuskiego pedagoga C. Freineta (Freinet 1976, Frankiewicz 2014).

\section{Technika swobodnych tekstów C. Freineta a rozwój mowy i myślenia}

Samą technikę jestem $\mathrm{w}$ stanie przedstawić tu jedynie $\mathrm{w}$ pewnym uproszczeniu. W organizacji zajęć tą techniką wyróżnić można kilka etapów, których rozwiązania szczegółowe mogą być różne, zależne w głównej mierze od zaawansowania językowego studentów.

Punktem wyjścia $\mathrm{w}$ omawianej koncepcji jest pisanie swobodnych tekstów. Swobodny tekst jest dowolną wypowiedzią pisemną, poprzez którą student wypowiada swoje myśli, przeżycia i spostrzeżenia na temat, który go właśnie interesuje lub na temat zasugerowany (nie narzucony, „zadany") przez wykładowcę. Forma wypowiedzi na tym poziomie kształcenia powinna być zamierzona, celowo dobrana. Może ona przybrać charakter ekspresji literackiej czy publicystycznej (opowiadanie, humoreska, scenariusz filmowy, esej, artykuł, komentarz do aktualnych wydarzeń, felieton, recenzja $\mathrm{i}$ in.). Najwartościowsze są takie teksty, które powstają w chwili, kiedy student odczuwa potrzebę wyrażenia swoich myśli i zakomunikowania ich innym. Dlatego mogą one być pisane zarówno w czasie zajęć w uczelni, jak i w domu (Freinet 1976, Frankiewicz 2014, Semenowicz 1995).

Następnym etapem jest głośne czytanie tekstów i wybór najlepszej pracy. Wyboru tego, odpowiednio argumentując, dokonują w sposób demokratyczny sami studenci. Należy w tym miejscu, za C. Freinetem, przestrzec przed zbytnią ingerencją wykładowcy, zarówno na tym etapie pracy, jak i w następnych. Ingerencja taka nie może deformować myśli autora tekstu. Trzeba respektować w niej to, co oryginalne i osobiste. Czytanie i głosowanie mogą odbywać się także w zespołach. Wówczas każdy z zespołów przedstawia jeden tekst do przegłosowania przez całą grupę studencką.

Kolejny etap, najbardziej przydatny $\mathrm{w}$ pracy nad doskonaleniem umiejętności językowych, to zbiorowe opracowywanie wybranego tekstu, który udostępniony za pomocą urządzeń wizualnych jest poprawiany, „wygładzany”, doskonalony. Jest to niełatwy etap pracy, ale mający duże wartości kształcące. Podstawowy cel to doprowadzenie wybranej wypowiedzi 
do postaci poprawnej językowo. Nie chodzi tu tylko o poprawność ortograficzną i gramatyczną. Tekst jest wspólnie przeżywany, analizowany i poprawiany po to, aby słowa najlepiej wdrażały sens myśli. Ważną pomocą będą tu słowniki (np. frazeologiczne, wyrazów bliskoznacznych) i inne źródła. Ćwiczenia w analizie tekstu opierają się na naturalnej potrzebie „rozjaśniania znaczenia".

Często sztucznie przeprowadzane na zajęciach językowych ćwiczenia gramatyczne, stylistyczne i ortograficzne tu - w dążeniu do najodpowiedniejszego wyrażenia treści - nabierają innego znaczenia, są wykonywane naturalnie. Stanowią po prostu środek do jasnego wypowiedzenia własnych myśli.

Student aktywnie uczestnicząc $\mathrm{w}$ doskonaleniu tekstu uczy się wyrażać myśli w sposób przekonywujący i precyzyjny, także i po to, aby sam mógł zrozumieć niuanse opanowywanego języka obcego. W pracy nad tekstem, polegającej na wyszukiwaniu oraz usuwaniu błędów i niejasności, a tym samym na doskonaleniu wypowiedzi, wyróżnimy za C. Freinetem trzy zasadnicze grupy ćwiczeń: 1) analiza tekstu ze względu na poprawność wyrażeń i zwrotów, 2) analiza treści ze względu na konstrukcję całości i budowę kolejnych zdań, 3) ćwiczenia uwzględniające precyzję języka (Frankiewicz 2014, Freinet 1976).

Ta nierozłączność w traktowaniu funkcji semantycznych (komunikatywnych) i niesemantycznych (ekspresywnych) języka obcego, $\mathrm{w}$ połączeniu $\mathrm{z}$ wiadomościami o tym języku może sprawić, że wspólna praca nad tekstem, integrująca sprawności językowe, będzie bardzo efektywna.

Przypisując swobodnej wypowiedzi studenta takie wartości jak: spontaniczność, twórczość czy ekspresja przeżyć nie twierdzę bynajmniej, że umiejętności językowe rozwiną się automatycznie, na przykład tylko dlatego, że uczący się dużo pisze. Bogacenie języka, przyswajanie nowych środków ekspresji odbywać się ma w trakcie analizy i opracowywania tekstu. Student jakby doświadczalnie, na własnej wypowiedzi przekonuje się, które środki pozwalają na pełniejszą ekspresję jego myśli, za pomocą jakich dodatkowych zdań, przydawek, epitetów, okoliczników odpowiadających wymaganiom składni oraz jakich słów i wyrażeń zdoła różne odcienie myśli uczynić bardziej zrozumiałymi (Frankiewicz 2014).

Chcąc zaproponować, aby technika swobodnych tekstów C. Freineta była nie tylko elementem pomocniczym, lecz stała się punktem wyjścia i punktem centralnym w pracy nad praktycznym opanowaniem języka obcego i intelektualnym rozwojem studentów w polskiej uczelni, warto podkreślić, że 
za jedną z zasadniczych wartości tej formy pracy uznana jest dyskusja studentów nad udoskonalaniem wytworów ich własnej ekspresji.

Metoda dyskusji wydaje się być wyjątkowo sprzyjająca w doskonaleniu wyrażania myśli w języku obcym i scaleniu kształcenia językowego $\mathrm{z}$ nauką o języku. Wynikać to może $\mathrm{z}$ faktu, że mimo ograniczeń formalnych (gramatyka), tkwiących w danym systemie językowym, istnieje szerokie pole swobodnego wyboru środków wyrazu w obrębie tego samego języka. Tę samą myśl można wyrazić poprawnie w bardzo różnorodny sposób. Miarą poprawności $\mathrm{w}$ doskonaleniu swobodnego tekstu będzie nieprzekraczanie systemu gramatycznego i równocześnie celność ujęcia $\mathrm{w}$ opanowywanym języku określonej kwestii. Wygenerowane pomysły, w postaci nowych propozycji zdań, wyrażeń, słów, poddawane są weryfikacji, której rezultatem jest wybór najtrafniejszego rozwiązania.

Semantyka treści wypowiedzi wpływa zasadniczo na jej gramatyczną strukturę, decyduje o ostatecznym kształcie. Aspekt semantyczny to nie tylko znaczenie poszczególnych słów, ale przede wszystkim system relacji łączących je z innymi słowami w zdaniu, czyli sens zdania. Większość psycholingwistów podkreśla decydującą rolę czynników semantycznych (czyli rozumienia treści) $\mathrm{w}$ procesie nabywania reguł syntaktycznych. Wynika stąd ważny postulat dydaktyczny o konieczności rozpatrywania zjawisk językowych w kontekście semantycznym (Dakowska 2008). Wydaje się, że pracując techniką swobodnych tekstów Freineta spełnimy ten warunek. Poszukiwanie najwłaściwszych środków wyrazu w celu nadania myślom jak najbardziej komunikatywnej postaci jest tu bezpośrednim kształceniem języka i myślenia.

Ujmując czynności werbalne podczas dyskusji nad doskonaleniem tekstu w kategoriach językoznawstwa, można wnosić, że dzięki tym czynnościom wzbogacane jest nie tylko słownictwo, ale także różnorodność zdań, czyli schematy syntaktyczne. Ponadto, nie można zapominać, że ważnym czynnikiem w uczeniu się języka jest częstość użycia określonych reguł gramatycznych w praktyce komunikacyjnej.

Natomiast, uwzględniając aspekt psychologiczny omawianego tu procesu, należy zauważyć za K. Obuchowskim (2004), że każdy tekst językowy (także wytwór ekspresji studentów), poddany analizie językowej wymaga najpierw zrozumienia. Jeżeli idea zawarta w komunikacie językowym, np. w zdaniu, ma być wyrażona $\mathrm{w}$ innej formie, za pomocą innych środków wyrazu, zdanie to musi być właściwie zrozumiane. Jest to warunek konieczny dla każdej transformacji zdania. Oznacza to, że nie wystarczy rozumieć poszczególne słowa w zdaniu, nie wystarczy również rozpoznać jego budowę gramatyczną. Zrozumienie zdania, tj. odnalezienie jego znaczenia ogólnego, oznacza 
rozumienie idei, której jest ono nośnikiem. Wówczas dopiero możliwe jest zastępowanie jednych zdań innymi o tym samym znaczeniu. $\mathrm{Na}$ bazie powyższych sądów można wysnuć twierdzenie, że praca nad językiem obcym techniką swobodnych tekstów staje się jednocześnie formą przygotowania do percepcji obcojęzycznej literatury i publicystyki.

Treści swobodnych tekstów, które wzbudziły szczególne zainteresowania studentów, mogą zapoczątkować różnorodne zajęcia i ćwiczenia szczegółowe, zmierzające do poznania, zbadania, wyjaśniania lub pogłębiania poruszonego wycinka wiedzy. Mogą one tym samym wykraczać poza ramy wąsko pojmowanego nauczania języka obcego. Takie działania C. Freinet nazywa „pedagogicznym wykorzystaniem swobodnego tekstu” (Freinet 1976). Można tu zaliczyć:

1. Zajęcia bezpośrednio związane $\mathrm{z}$ treścią opracowywanych tekstów jak: przygotowywanie referatów, wywiady (z nosicielami danego języka obcego), poszukiwania $\mathrm{w}$ materiałach źródłowych, $\mathrm{np}$. $\mathrm{z}$ zakresu kultury, historii lub geografii w celu pogłębienia wiadomości zawartych w tekstach $\mathrm{i}$ in.

2. Zajęcia bezpośrednio związane $\mathrm{z}$ przygotowaniem i wydawaniem $\mathrm{w}$ ramach instytutu (katedry) gazetki ${ }^{2}$ wraz $\mathrm{z}$ prowadzeniem korespondencji $\mathrm{z}$ innymi ośrodkami akademickimi (gromadzenie i wysyłanie korespondencji itd.). Prace związane $\mathrm{z}$ wydawaniem gazetki i korespondencją międzyuczelnianą mogą sprawić, że wysiłek studentów nabierze sensu społecznego. Każdy tekst może praktycznie, po odpowiednim opracowaniu, stać się artykułem w instytutowej (wydziałowej) gazetce lub dotrzeć do korespondentów. W takim przypadku przygotowujący tekst będzie pisał nie tylko o tym, co go interesuje, lecz także i to, co w jego myślach, uczuciach i działaniu mogłoby zaciekawić innych. Fakt ten może sprawiać, że autor tekstu będzie starał się nadać swoim myślom jak najlepszą formę.

Istotnym z punktu widzenia rozwoju języka i stymulacji twórczego myślenia elementem techniki swobodnych tekstów jest swobodna, twórcza atmosfera pracy. Najważniejszymi czynnikami, składającymi się na ową pożądaną atmosferę są: poszanowanie godności studenta, liczenie się z jego zainteresowaniami, nadawanie czynnościom studiujących rangi spraw

2 Gazetka taka zgodnie z koncepcją Freineta, to zbiór tekstów pisanych, drukowanych i powielanych przez studentów (Freinet 1976, Semenowicz 1995). 
ważnych. Podczas zajęć audytoryjnych studenci powinni mieć pewien stopień swobody, dotyczącej organizacji pracy i podejmowania zadań.

Nie oznacza to dowolności. Ogólne cele dydaktyczne muszą być uwzględnione i realizowane. Wykładowca $\mathrm{w}$ takich warunkach spełniać ma rolę doradcy, powinien kierować całością pracy, pomagać, rozstrzygać sporne kwestie. Nigdy zaś autorytatywnie nie decyduje (Freinet 1972).

Znaczącym elementem twórczej atmosfery jest poszanowanie i akceptowanie wyrażonej w języku obcym samodzielnej myśli studentów. Każdy $\mathrm{z}$ nich powinien być przekonany, że wytwór jego ekspresji, uzewnętrznione przeżycia, poglądy i krytyczne oceny nie będą zlekceważone czy wyśmiane przez kolegów, ani też formalnie ocenione przez wykładowcę. Chodzi zwłaszcza o to, aby motywacja lękowa zredukowana została do minimum. C. Freinet nazywa takie zabiegi ,uwolnieniem pedagogicznym" uczących się (Freinet 1976, Frankiewicz 2014, Semenowicz 1995).

W literaturze pedagogicznej i psychologicznej dominuje przekonanie o potrzebie stworzenia $\mathrm{w}$ procesie nauczania klimatu pedagogicznego sprzyjającego rozwojowi studiujących. Powszechnie postuluje się potrzebę i konieczność takiego kierowania w procesie uczenia się, które charakteryzuje się „wyzwalającym” a nie „hamującym” stosunkiem wykładowcy. I tak, np. C. Rogers, wskazując na dwa najważniejsze czynniki sprzyjające realizacji możliwości twórczych: świadomość bezpieczeństwa i poczucie wolności, stwierdza, że twórczość wymaga swobodnego i życzliwego, pozbawionego elementów krytyki i nacisku klimatu emocjonalnego (Rogers 1963, 2012). Myśli te znajdują potwierdzenie w rozważaniach J. Reykowskiego. Zdaniem tego autora czynności twórczego myślenia przebiegają najkorzystniej $\mathrm{w}$ atmosferze swobody i życzliwości, w klimacie emocjonalnym pozbawionym przymusu, nacisku i krytyki. Niekorzystną sytuację, zewnętrzną stwarza zaś „sztywna” i surowa atmosfera wywołująca stany lękowe, stres emocjonalny (Reykowski 1992). Także K. Obuchowski (2004) eksponuje z naciskiem namysł, że twórcze możliwości mózgu mogą się ujawniać tylko w warunkach dominacji emocji dodatnich.

\section{Podsumowanie}

Wszystkie zajęcia językowe w oparciu o technikę swobodnych tekstów mogą być prowadzone $\mathrm{w}$ formie indywidualnej lub zespołowej, tylko omawianie i poprawianie tekstu odbywa się $\mathrm{w}$ formie zbiorowej (choć może przebiegać także w zespołach). Według Freineta daje to szansę na tworzenie 
wartościowych interakcji, rodzaju wspólnoty i na polepszenie atmosfery $\mathrm{w}$ grupie. Być może istnieje tu szansa na zmniejszenie, obserwowanej w naszych polskich warunkach, postępującej dezintegracji zespołów studenckich.

Należy jednak zdawać sobie sprawę, że na poziomie studiów wyższych swobodne teksty mogą nie wystarczyć do nauki i doskonalenia języka obcego. Student musi mieć stały kontakt z literaturą piękną o wysokim poziomie artystycznym (Freinet 1961), co w przypadku studiów neofilologicznych wydaje się rozwiązaniem całkowicie realnym. To obcowanie z literaturą piękną ma służyć nie tylko przyswajaniu przez studentów środków i wartości artystycznych, czy też bogaceniu przeżyć estetycznych i wiedzy. Teksty wielkich autorów mają także pomoc $\mathrm{w}$ zrozumieniu ogromnych możliwości języka w przedstawianiu różnorodnej rzeczywistości. Przypomina się tu konieczność kontaktu studentów z treściami i formami kultury wytworzonymi przez nosicieli nauczanego języka.

Oceniając w tym podsumowaniu wartości tkwiące we freinetowskiej technice swobodnych tekstów proponuję spojrzeć na tę koncepcje jako na bogate źródło inspiracji, mogące odegrać dużą rolę $\mathrm{w}$ przebudowie i wzbogacaniu form organizacji pracy nad opanowaniem języków obcych w polskich uczelniach. Pojawiają się możliwości oparcia pracy nad doskonaleniem umiejętności językowych na inteligencji, dynamice, ekspresji przyszłych nauczycieli języków oraz przekonanie o korzyści łączenia rozwoju językowego z rozwojem myślenia i postaw twórczych.

Eksponowane we freinetowskiej pedagogii $\mathrm{i}$ pokazane $\mathrm{w}$ tym opracowaniu myślenie o znaczącej roli współpracy i kreatywności w procesie uczenia się, to problematyka poparta także wynikami współczesnych badań europejskich i polskich. Pokazują one potrzebę integrowania gramatyki i poszczególnych sprawności językowych z kompetencjami społecznymi realizowanymi przez język oraz akcentują techniki kreatywności i zespołowości uczące angażowania różnorodności w edukacji językowej (Bekteshi 2017, Angell, Lightbown, Spada 2006.), a także doskonalące umiejętności interpersonalne przygotowujące do radzenia sobie z trudnościami. (SobańskaJędrych, Karpeta-Peć, Torenc 2013).

\section{BIBLIOGRAFIA}

Aleksander, Z. \& Frankiewicz, W. (2014). Psychopedagogiczna i socjolingwistyczna interpretacja wartości freinetowskiej pedagogii w edukacji akademickiej. W: A. Semenowicz, 
H. Solarczyk, A. Szwech (red.). Inspiracje pedagogią freinetowską. Studia, refleksje, wspomnienia dedykowane Halinie Semenowicz. Toruń: Wyd. Naukowe UMK.

Angell, J., Lightbown, P.M. \& Spada, N. (2006). How Languages Are Learned, Modern Language Journal Vol.79(2), 268-269.

Bekteshi, E. (2017). The perception of collaboration and creativity in language teaching and learning. Knowledge - International Journal, Vol. 19.3, 1131-1135.

Dakowska, M. (2008). Psycholingwistyczne podstawy dydaktyki języków obcych. Warszawa: PWN.

Frankiewicz, W. (2014). Technika swobodnych tekstów jako metoda kształcenia myślenia twórczego. Warszawa-Otwock: PSAPCF.

Freinet, C. (1961). La methode naturelle de lecture. Cannes: BEM.

Freinet, C. (1963). La methode naturelle de grammaire. Cannes: BKM.

Freinet, C. (1972). Naissance d'une pedagogie populaire". Paris: Ed. MASPERO.

Freinet, C. (1976). O szkołę ludową. Pisma wybrane. Wrocław-Warszawa-Kraków-Gdańsk: Ossolineum.

Obuchowski, K. (2004). Kody umysłu i emocje. Łódź: WSHE.

Rogers, C. R. (1963). Learning to be free. In: S. M. Farber, R. H. Wilson (Eds.), Conflict and Creativity: Control of the Mind, Part 2. New York: McGraw Hill Paperbacks.

Rogers, C. R. (2012). Sposób bycia. Poznań: REBIS.

Rutkowiak, J. (2016). Pomyśleć szkołę inaczej w warunkach złożoności świata. Studia i Badania Naukowe. Pedagogika 1, 35-51.

Semenowicz, H. (1995). Nowoczesna szkoła francuska technik Freineta. Warszawa-Otwock: PSAPCF.

Sobańska-Jędrych, J., Karpeta-Peć, B. \& Torenc M. (2013). Rozwijanie zdolności językowych na lekcji języka obcego. rozdz. III. Warszawa: ORE.

Wygotski, L.S. (1989). Myślenie i mowa. Warszawa: PWN. 